\title{
Gas exchange and biomass production in young plants of Acapu (Voucapoua americana Aubl.) subjected to drought condition
}

\author{
Joze M. N. de Freitas ${ }^{1}$, Kerolém P. S. Cardoso ${ }^{1 *}$, Glauco A. dos S. Nogueira ${ }^{1}$, Vitor R. do Nascimento ${ }^{1}$, \\ Cândido F. de Oliveira Neto ${ }^{1}$, Roberto C. L. da Costa ${ }^{1}$, Diocléa A. S. Silva ${ }^{1}$, Allan K. da S. Lobato ${ }^{3}$, \\ Ismael de J. M. Viégas ${ }^{2}$
}
${ }^{1}$ Institute of Agrarian Sciences, Laboratory of Biodiversity Studies of Upper Plants in Federal Rural University of Amazonia, Pará, Brazil
${ }^{2}$ Laboratory of Biodiversity Studies of Upper Plants in Federal University Rural of Amazônia, Capanema city, Brazil
${ }^{3}$ Core Research and Plant Production, Federal University Rural of Amazônia, Paragominas city, Brazil

*Corresponding author: k.cardoso.agro@gmail.com

\begin{abstract}
The experiment was conducted in a greenhouse at the Federal Rural University of Amazonia (UFRA) from November 2011 to July 2012. The plants were subjected to two water regimes: control (adequate irrigation) and water deficiency (water suspension) for 0 , 10, 20 and 30 days period. The water potential in stressed plants was reduced after 30 days of drought. The photosynthetic rate, stomatal conductance and transpiration rate were reduced with increased water stress time in plant with more pronounced reductions in the $20^{\text {th }}$ and $30^{\text {th }}$ after induction of treatments. The concentration of ABA increased in leaves and roots of plants submitted to water deficit. Dry mass of shoot, root and total mass were decreased in plants under water stress. The suspension of irrigation for 10 days was sufficient to alter the metabolism of young Acapu plants. These results showed that young Acapu plants tolerate a water potential of up to $-2.86 \mathrm{MPa}$, indicating that this species is not susceptible to water stress/suspension. This condition may favor the development and expansion of Voucapoua americana for the recovery of degraded areas in regions with limited available water.
\end{abstract}

Keywords: ABA; stomatal conductance; photosynthesis; transpiration; water deficiency.

Abbreviations: A_photosynthetic; ABA_abscisic acid; ATP_adenosine triphosphate; DM_dry mass; E_transpiration; FM_fresh mass; GGH_gamma-glutamyl hydrolase; $g_{s-}$ stomatal conductance; PVPP_polyvinypolyrrolidone; RWC_relative water content; VPD_vapor pressure deficit; $\Psi \Psi_{\mathrm{w}}$ water potential.

\section{Introduction}

The species Vouacapoua americana Aubl., commonly known as Acapu, belongs to the Fabaceae family and the Faboideae subfamily. It exists in the Amazon region in Brazil, mainly in the states of Pará and Amapá in the rain forest and also in the Guianas. Its wood has great economic importance, being used mainly in the civil and naval construction. Its bark is medicinal with antiseptic properties, being used in the form of ointment. It is considered a good species for reforestation of degraded areas (Lorenzi, 2009).

According to Nascimento et al., (2011) the Brazilian tree species have attracted the interest of many researchers due to their adaptive behaviors that facilitate their potential use in areas with unfavorable condition, making it of great silvicultural and economic importance.

There are regions in the Amazon, like Southeast of Pará, where periods of severe water deficit occur, with periods of rainfall below $40 \mathrm{~mm}$ more than 4 months. The climate of the Amazon is humid and warm almost all year round, with an average temperature of $25^{\circ} \mathrm{C}$, little fluctuating along the seasons (Neiman, 2012).

The water deficit is one of the main limiting factors of development and growth of plants. Only species with drought resistance mechanisms can thrive in environments with water limitation (Ferreira et al., 2006). Water deficiency in the soil severely limits the growth and development of plant species in regions of the world, and particularly in the northeastern and northern regions of Brazil, where the distribution of water resources is irregular (Gonzáles et al., 2012).

One of the main strategies have been used for a long time is the development of drought-tolerant plant varieties through genetic improvement. However, it is necessary to understand the physiological and biochemical response mechanisms of the species to this type of stress. According to Nogueira et al. (2000), water deficiency affects all aspects of plant growth and development and may influence cell elongation and differentiation as a function of the reduction in cell turgor, which results in decrease of leaf area, affecting the production and the translocation of photo-assimilates to the new growth areas (Larcher, 2006). The lack of water in the soil also affects the synthesis of proteins and the activity of some enzymes such as nitrate reductase (Salisbury and Ross, 2012).

According to Scalon et al. (2011), several native tree species have potential for cultivation and can serve various purposes whether for ornamental, timber, food or preservation. Therefore, the improvement of the seedling production system of native tree species is necessary due to the increase in the demand for commercial production of 
these species, as well as for the recovery of degraded areas.

The aim of this study was to analyze the parameters of gas exchange related to the production of biomass, as well as the water potential, relative water content and ABA concentrations in leaves and roots of Voucapoua americana Aubl. subjected to water stress., It is expected that this study adds the knowledge of use the Acapu in the reforestation of degraded areas in a more conscious way. Also, the results can be used in the other species with forest potential.

\section{Results and Discussion}

\section{Water potential}

The water potential of plants maintained under water deficiency significantly reduced throughout the experiment, while the irrigated plants maintained a constant average of $0.67 \mathrm{MPa}$, in which the values for the stressed plants were $0.66 ;-1.62 ;-2.56$ and $-2.86 \mathrm{MPa}$ at $0,10,20$ and 30 days of water deficit, respectively (Fig 1). The water potential is used as a measure of the water status of plant, in addition to governing the transport of water through the cell membranes. However, plants may present a very negative water potential in drought conditions. In general, this type of stress promotes accumulation of solutes in the cytoplasm and in the vacuole of plant cells, allowing the cells to maintain the turgor pressure despite the low water potential (Taiz and Zeiger, 2013).

According to Pagter et al. (2005), the accumulation of these compounds in leaves decreases leaf water potential, which increases the water absorption capacity of plants and attenuates the effects of water deficiency on the relative water content of the plant. Silva (2009), also observed a marked decrease in the water potential of young plants of Carapa guianensis Aubl., with an increase in water deficit time, during 27 days, in a greenhouse.

\section{Relative water content}

The relative water content of plants under water deficit were significantly reduced over time, compared to irrigated plants (control). Irrigated plants kept average of $83.93 \%$ over the experiment. The values presented by plants subjected to water stress were $83.98 \%, 74.25 \%, 66.70 \%$ and $52.79 \%$ equivalent to $0,10,20$ and 30 days of water stress (Fig 2).

This decrease promotes deformation of cell wall and rupture of the membranes of chloroplasts and mitochondria and other organelles, reducing the activity of membrane-associated reactions such as the biochemical activity of photosynthesis (Jones, 2007), in which the possible closure of stomata is taken as a strategy for the maintenance of the plant during the period of water suspension.

Thus, the maintenance of the water status of the plants through stomatal closure occurs in response to the signaling triggered by abscisic acid (Hong Bo et al., 2008). Albuquerque et al. (2013) observed a 28\% reduction in CRA on African mahogany under greenhouse conditions (control and water deficit) at 14 days of water stress.

\section{Photosynthetic}

The photosynthetic rate was significantly decreased in plants under water stress from the 10th day of water stress but did not differ statistically in the values observed at 20 and 30 days of water deficit (Fig 3). Irrigated plants kept constant photosynthesis with an average of $2.91 \mu \mathrm{mol} \mathrm{m}^{-2} \mathrm{~s}^{-1}$ between treatments. The photosynthetic values were $3.09,1.16,0.28$ and $0.02 \mu \mathrm{mol} \mathrm{m} \mathrm{m}^{-2} \mathrm{~s}^{-1}$ in the plants subjected to water stress for $0,10,20$ and 30 days of drought stress, respectively. At 20 days of stress, photosynthesis was not statistically different neither at 10 nor 30 days of water suspension.

According to Flexas and Medrano (2002), the reduction of photosynthesis in plants subjected to water deficiency may occur for different reasons, such as stomatal limitation of $\mathrm{CO}_{2}$ entry, damage to the photochemical apparatus of photosynthesis, reduction in ATP synthesis, and decrease in the activity of Rubisco (Ribulose-1,5-bisphosphate carboxylase oxygenase) or in rate of regeneration. Results obtained by Santana (2012) working with Jatropha curcas L. plants show decreased photosynthesis in plants under water deficiency.

\section{Stomatal conductance}

The stomatal conductance was decreased significantly in plants under water deficit, compared to irrigated plants (Fig 4). However, no significant difference in values of gas between 20 and 30 days of water deficiency was observed. The values found were $0.06,0.03,0.01$ and $0.01 \mathrm{~mol} \mathrm{~m}^{-2} \mathrm{~s}^{-1}$ in plants submitted to water deficiency for $0,10,20$ and 30 days of water stress, respectively. The plants kept under control had a mean of $0.06 \mathrm{mmol} \mathrm{m}{ }^{-2} \mathrm{~s}^{-1}$. As the drought was increased, there was dehydration of mesophyll cells and decreased water potential of leaves (Fig 1), reducing photosynthesis (Fig 3) and stomatal conductance.

The stomatal closure represents the first cause of the reduction in the photosynthetic rate and the rate of transpiration under water deficiency conditions. This reduction is due to the decrease in $\mathrm{CO}_{2}$ availability in the leaf sub-stomatal chambers caused by stomata closure (Gonçalves et al., 2009). One of the first responses to water deficiency is the reduction in stomatal conductance and longer periods of stress can cause limitations in photosynthesis and plant growth (Centritto, 2003).

This reduction of the stomatal pore aperture restricts the exchange of gases between the interior of the leaf and the atmosphere causing a decrease in $\mathrm{CO}_{2}$ assimilation that is used in the photosynthetic process (Larcher 2006). Similar results were observed in Khaya ivorensis plants (Albuquerque et al., 2013), which demonstrated a reduction in stomatal conductance under conditions of water deficiency.

\section{Transpiration}

The leaf transpiration was significantly reduced under water deficit, compared to control irrigated plants (Fig 5). The trend followed a similar way to the stomatal conductance in plants subjected to water deficiency (Fig 4). There was a significant reduction from the $10^{\text {th }}$ day of irrigation suspension. However, this reduction was statistically similar to 20 and 30 days of water deficit. The average of the values maintained in plants irrigated was $1.56 \mathrm{~mol} \mathrm{~m} \mathrm{~m}^{-1}$, while the values obtained in water deficient plants was $1.55 ; 0.91 ; 0.31$ and $0.19 \mathrm{~mol} \mathrm{~m}^{-2} \mathrm{~s}^{-1}$ for the treatments with $0,10,20$ and 30 days, respectively.

The reduction of transpiration occurs due to stomatal closure, which is promoted by increased biosynthesis or redistribution of $\mathrm{ABA}$. This decrease in perspiration may be linked to stomatal behavior throughout stress, possibly due to the potential of leaf water and its relation with the potential of soil water, besides other environmental factors such as light 


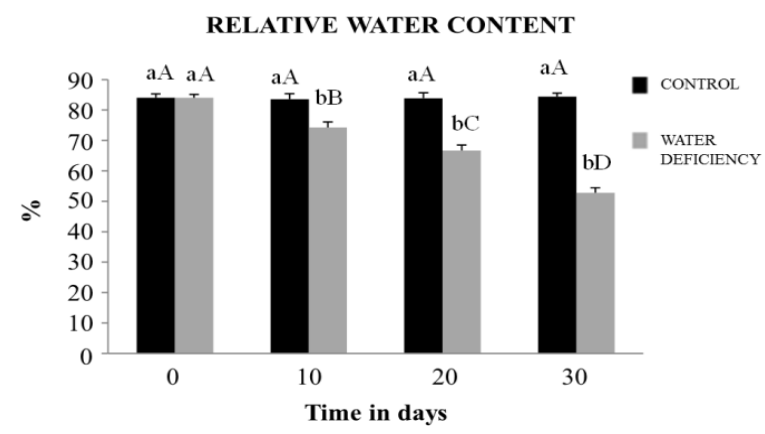

Fig 1. Water potential in leaves of young acapu plants (Vouacapoua americana Aubl.) submitted to drought. The averages followed by the same uppercase or lowercase do not differ by Tukey test at 5\% probability. Lowercase letters compare the values of water regimes and capital letters compare values throughout the experiment. The bars represent the mean standard deviations.

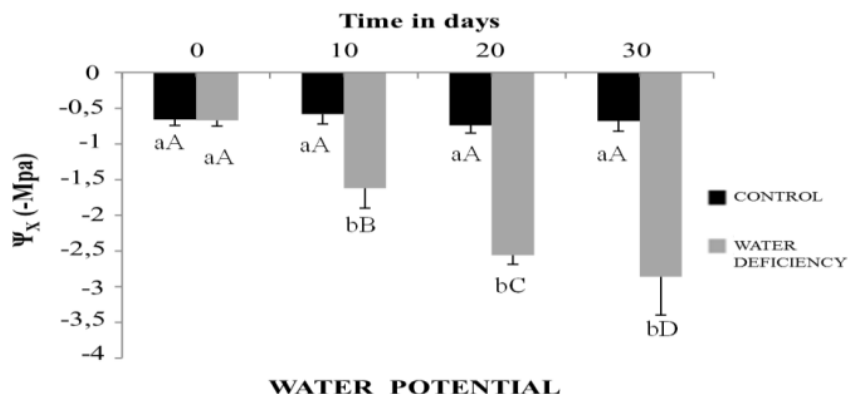

Fig 2. RWC in leaves of acapu plants (Vouacapoua americana Aubl.) submitted to drought. The averages followed by the same uppercase or lowercase do not differ by Tukey test at 5\% probability. Lowercase letters compare the values of water regimes and capital letters compare values throughout the experiment. The bars represent the mean standard deviations.

PHOTOSYNTHESIS

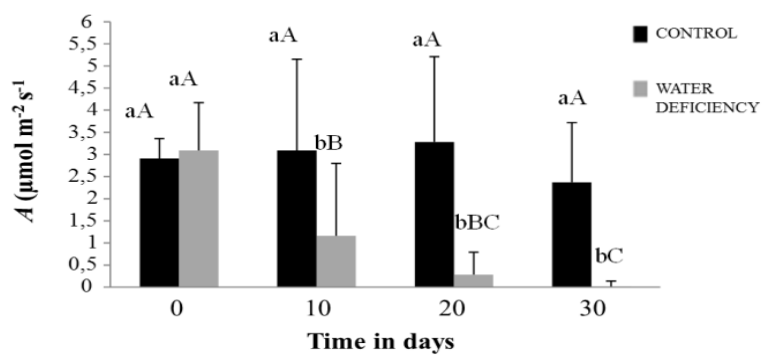

Fig 3. Photosynthesis in leaves of acapu plants (Vouacapoua americana Aubl.) submitted to drought. The averages followed by the same uppercase or lowercase do not differ by Tukey test at 5\% probability. Lowercase letters compare the values of water regimes and capital letters compare values throughout the experiment. The bars represent the mean standard deviations.

\section{STOMATAL CONDUCTANCE}

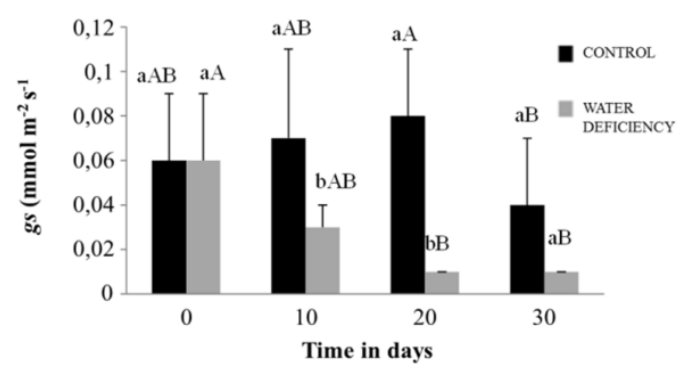

Fig 4. Stomatal conductance of acapu (Vouacapoua americana Aubl.) submitted to drought. The averages followed by the same uppercase or lowercase, do not differ by Tukey test at $5 \%$ probability. Lowercase letters compare the values of water regimes and capital letters compare values throughout the experiment. The bars represent the mean standard deviations. 


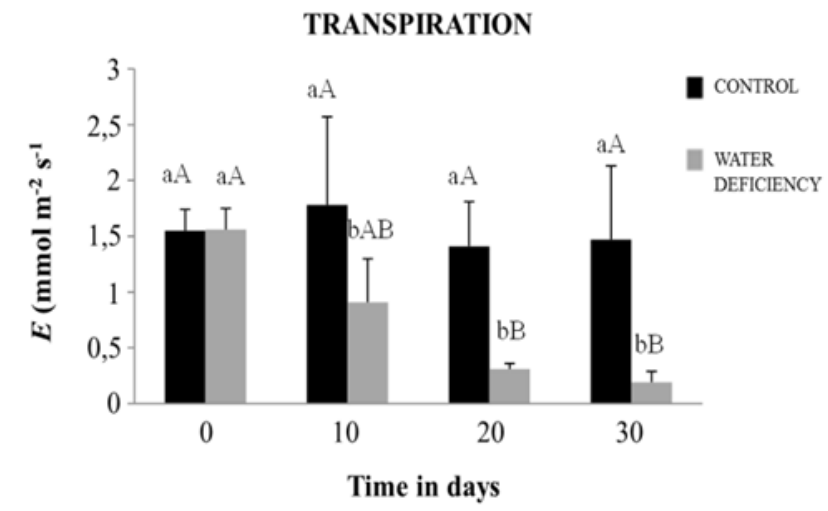

Fig 5. Transpiration in leaves of acapu (Vouacapoua americana Aubl.) submitted to drought. The averages followed by the same uppercase or lowercase do not differ by Tukey test at $5 \%$ probability. Lowercase letters compare the values of water regimes and capital letters compare values throughout the experiment. The bars represent the mean standard deviations.

ABA CONCENTRATION IN LEAVES

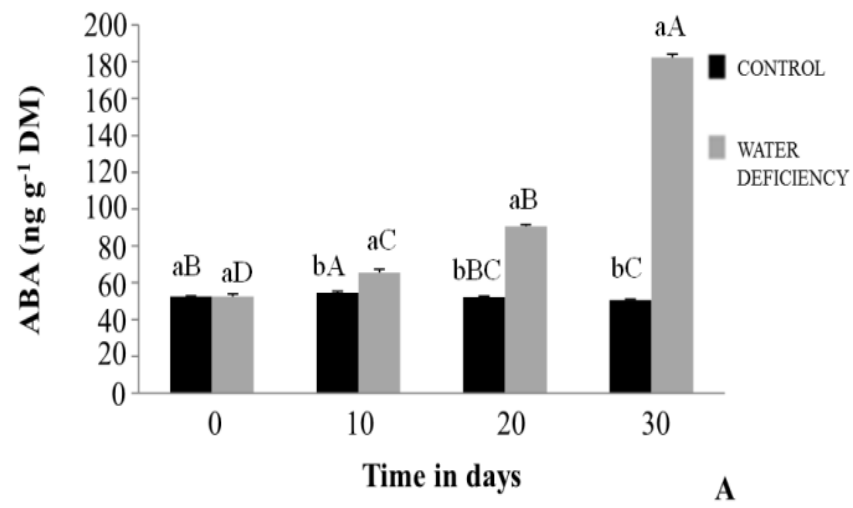

ABA CONCENTRATION IN ROOTS

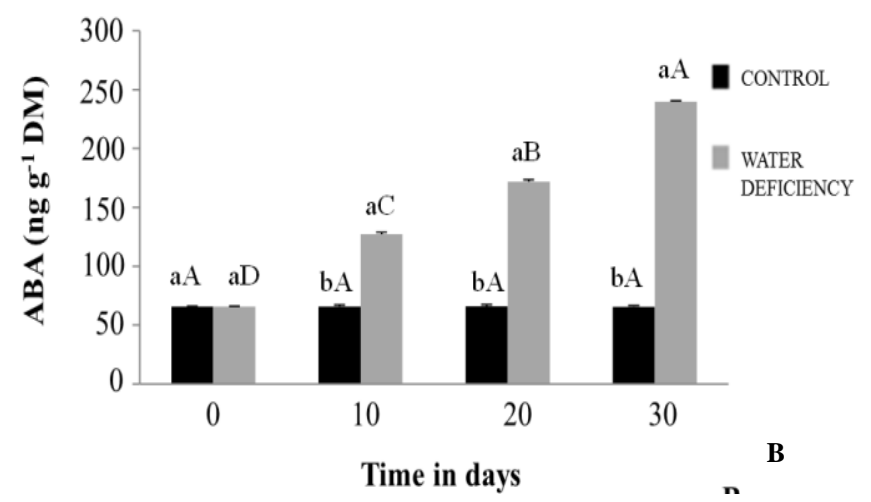

Fig 6. ABA content in leaves and roots of acapu (Vouacapoua americana Aubl.) submitted to drought. The averages followed by the same uppercase or lowercase do not differ by Tukey test at $5 \%$ probability. Lowercase letters compare the values of water regimes and capital letters compare values throughout the experiment. The bars represent the mean standard deviations. 
DRY MASS PART AIR

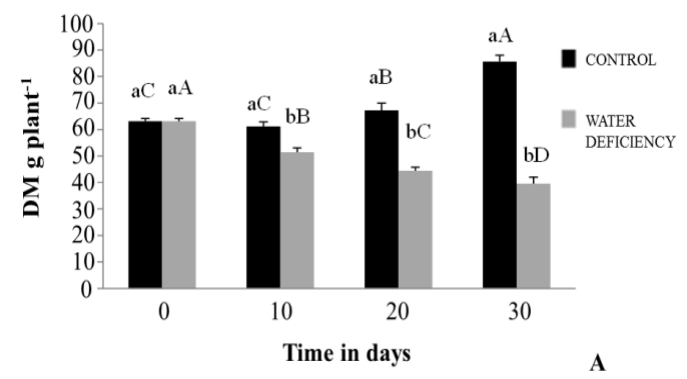

DRY MASS ROOT

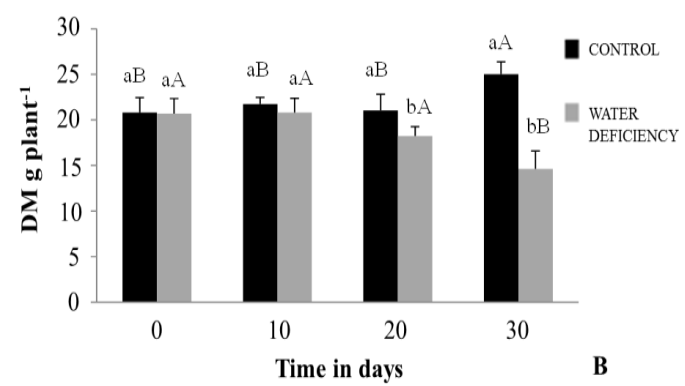

DRY MASS TOTAL

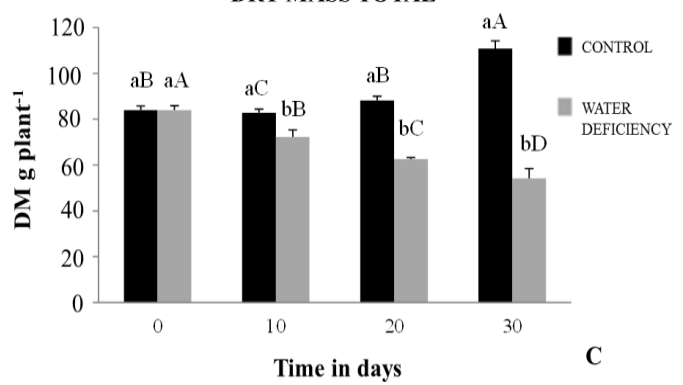

Fig 7. Dry mass part aerial (A), dry mass of root (B) and total dry mass (C) of acapu plants (Vouacapoua americana Aubl.) submitted to drought. The averages followed by the same uppercase or lowercase do not differ by Tukey test at $5 \%$ probability. Lowercase letters compare the values of water regimes and capital letters compare values throughout the experiment. The bars represent the mean standard deviations.

and relative humidity (Nogueira et al., 2000). A similar response was found by Silva (2009), who observed a decrease in the transpiration rate of plants Schinus terebinthifolius under water deficit in greenhouse.

\section{Concentration of abscisic acid}

The concentration of abscisic acid in leaves and roots of Acapu was significantly increased with time of water deficiency compared to control plants. The average levels of ABA in leaves and roots of irrigated plants were $52.43 \mathrm{ng} \mathrm{g}^{-1}$ DM (Fig 6A) and $65.78 \mathrm{ng} \mathrm{g}^{-1} \mathrm{DM}$ (Fig 6B), respectively. Concentration of abscisic acid in leaves of water deficit plants were $54.44,65.64,90.62$ and $182.39 \mathrm{ng} \mathrm{g}^{-1} \mathrm{DM}$ at 0 , 10,20 and 30 days of stress, respectively. The values for the roots were $65.78,127.30,171.77$ and $239.74 \mathrm{ng} \mathrm{g}^{-1} \mathrm{DM}$ at the same interval of times.

The decrease of water in the soil promoted the increase of the abscisic acid production in the plant, which acts on the stomatal mechanism, being one of the first symptoms of the plants when they perceive the stress (Zhang and Outlaw, 2001). One of the main functions of the ABA is to promote stomatal closure and to avoid the loss of water by transpiration in plants under water deficiency (Sharp et al., 2004).

Alves (2010) also found similar results in young plants of Tabebuia serratifolia submitted to lack of water and to flooding in greenhouse, where an increase in ABA concentration was observed, both in leaves and in roots under water deficiency.

\section{Dry mass of aerial part, root dry mass and total dry mass}

The water deficiency has significantly reduced the dry mass of aerial part (Fig 8A), root (Fig 8B) and total dry mass (Fig $8 \mathrm{C}$ ). But the effect of time on the dry mass of the root was only observed in plants with 30 days of water deficiency.

The dry mass of aerial parts was decreased significantly during the experiment in the stressed plants. The values obtained in control plants were $63.1 \mathrm{~g}, 61.0 \mathrm{~g}$, and $67.2 \mathrm{~g}$, $85.7 \mathrm{~g}$ at $0,10,20$ and 30 days of drought, respectively. Plants submitted to water deficit showed the values $63.1 \mathrm{~g}, 51.4 \mathrm{~g}$ and $44.4 \mathrm{~g}, 39.5 \mathrm{~g}$ at $0,10,20$ and 30 days, respectively.

The reduction of dry mass in aerial part of plants subjected to lack of water is possibly due to the decrease in the photosynthetic rate of these plants, which reduced the production of photoassimilates, as well as the possible 
changes in the metabolism of the plant. These results are similar to those found by Santiago (2000), which observed a reduction in dry mass of aerial part in young plants of Mimosa caesalpiniifoli subjected to water deficiency. For dry mass of the roots, there was a significant decrease only in the 30 th day of water deficiency, whereas value was $14.6 \mathrm{~g}$. The average of plants under control was $22.1 \mathrm{~g}$. Oliveira Neto (2010) worked on Hymenaea courbaril L. plants subjected to 30 days of water stress in a greenhouse and observed a reduction in the dry mass of the roots of these plants under water reduction.

The suspension of irrigation for 10 days significantly affected the total dry mass of acapu plants throughout the experiment. The values obtained for the total dry matter in plants under water control were $83.9 \mathrm{~g}, 82.8 \mathrm{~g}, 88.2 \mathrm{~g}, 110.7 \mathrm{~g}$ at $0,10,20$ and 30 days, respectively. In plants under drought condition the total mass values were $83.0 \mathrm{~g}, 72.2 \mathrm{~g}, 62.6 \mathrm{~g}$, $54.1 \mathrm{~g}$ at $0,10,20$ and 30 days, respectively. Junior (2008), worked with two castor bean cultivars subjected to water suspension and observed a decrease in total dry mass in the plants under water deficiency compared to the irrigated plants.

Water deficiency is one of the major conditions that limit the primary production of ecosystems and crop yields, mainly due to the restrictions that impose the carbon fixation (Grisi et al., 2008). According to Kozlowski (1984), the lack of water in the soil affects the development of the plants, reducing the dry mass of roots and aerial part. According to Larcher (2006), the effects of drought on vegetables depend on the intensity of the stress, the genetics of the plant and the duration of the stress, which can cause several ecophysiological changes in the plant.

\section{Materials and Methods}

\section{Location and growth conditions}

The experiment was conducted in a greenhouse at the Federal Rural University of Amazonia (UFRA), Brazil, from November 2011 to July 2012. The three-month-old seedlings of Acapu were obtained from Embrapa Eastern Amazon. These plants were acclimated for 2 months in the greenhouse. After this period, the Acapu plants were selected evenly considering height, stem diameter, number of leaves and number of leaflets and were transplanted into pots with $30 \mathrm{~cm}$ x $30 \mathrm{~cm}$, with capacity for $28 \mathrm{~kg}$ of substrate with mixture of 3: 1: 1 (v: v: v), superficial sandy soil, aviary bed and earthworm humus.

\section{Plant material conditions}

The plants were subjected to two water regimes: control (adequate irrigation) and water deficiency (water suspension) for $0,10,20$ and 30 days. Biomass production was measured in the act of every destructive collect, where the plants were separated into shoot and roots. The biomass was measured following a forced oven drying circulation at $70^{\circ} \mathrm{C}$ for 72 hours and then the root dry mass, dry mass of aerial part and total dry mass were determined in an analytical balance.

\section{Environmental and biophysical variables}

Air temperature averages $\left(\mathrm{T}_{\mathrm{ar}}\right)$, relative humidity $(\mathrm{RH})$ and air and leaf temperatures $\left(\mathrm{T}_{\text {fol }}\right)$ were evaluated by portable meter IRGA (Infra-red Gas Analyser/ADC equipaments mod. LCi 6400, Hoddesdon, UK). The minimum and maximum air temperature during the data collection of the experiment ranged from $25.3-39.5^{\circ} \mathrm{C}$. The relative humidity of the air varied between $62.5 \%-89 \%$. The mean of the photosynthetically active radiation was $870 \mu \mathrm{mol}^{-2} \mathrm{~s}^{-1}$. The average leaf temperature was of $36.9^{\circ} \mathrm{C}$ in the plants maintained under irrigation and $37.9^{\circ} \mathrm{C}$ in the plants under water deficiency and the VPD varied from $1.92 \mathrm{KPa}$ a 2.92 $\mathrm{KPa}$.

The water potential was determined between 08:00 a.m. and 10:00 a.m., by means of a pressure pump of the type Scholander (m670, Pms Instrument Co., Albany, USA). As samples, mature and fully expanded leaves were selected of the second or third pair of leaves from the apex.

\section{Gas exchange}

The stomatal conductance, transpiration, leaf temperature $\left(\mathrm{T}_{\mathrm{fol}}\right)$, photosynthesis and $\mathrm{CO}_{2}$ concentration in air and leaf

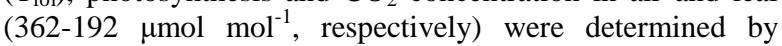
means of the IRGA portable meter. Measurements were performed between 09:30 a.m. and 10:30 a.m., time determined curve by the photosynthesis $x$ time. Gaseous exchanges were measured when the photosynthetic photons flux density was greater than $870 \mu \mathrm{mol} \mathrm{m} \mathrm{m}^{-2} \mathrm{~s}^{-1}$.

\section{Relative water content}

The relative water content was determined according to the method used by Slavick (1979), in which the mass of the same $\left(\mathrm{FM}_{1}\right)$ was weighed in analytical balance after the disks were transferred into petri dishes containing $35 \mathrm{~mL}$ of distilled water and left for a period of $6-7$ hours at $25^{\circ} \mathrm{C}$. Then, the discs were placed on filter paper to remove excess water and then weighed to determine the turgid mass $\left(\mathrm{FM}_{2}\right)$. After the discs were placed in paper bags and taken to the stove $\left(70^{\circ} \mathrm{C}\right)$ for $24 \mathrm{~h}$, the dry mass of the discs (DM) was determined and the results expressed as a percentage:

$$
R W C=\frac{F M 1-D M}{F M 2-D M} \times 100
$$

\section{Determinations of abscisic acid}

The ABA determinations were carried out in Plant Physiology Laboratory at Unicamp (Universidade de Campinas). Ross et al. (2004) protocol with some modifications was used for extraction and purification of ABA. The oven dried tissue was ground and macerated in liquid nitrogen $100 \%$ PVPP.

Chromatographic separation of the leaves and root samples were made in a high performance liquid chromatograph (Shimadzu, Japan) coupled with a triple mass spectrometer quadrupole (Micromass, Quattro II model with Z-SprayTM source, Manchester, United Kingdom), in which the HPCL had two LC-advp pumps, a detector UV / VIS SPD-10ADVP a SIL-10ADVP auto-injector and SCL-10AVP system controller.

Analyses were performed by liquid chromatography-mass spectrometry in negative electrospray ionization mode (HPLC / MS / ESI). The samples were analyzed using a C-18 column chromatography Supelcosil (Supelco; comprimentro $15 \mathrm{~cm} \times 4.6 \mathrm{~mm}$ internal diameter, $5 \mathrm{~mm}$ particle size) at a flow rate of $0.3 \mathrm{~mL} \mathrm{~min}^{-1}$.

The data were processed by MassLynx NT software (version 3.2, Micromass, Altricham, UK). The detection and quantification of $\mathrm{ABA}$ in the samples were made by the 
multiple reaction monitoring $(\mathrm{MRM})$ via the selection of transition density of the molecule of interest (for ABA, 263153, and to ABAd4, 267-156).

\section{Experimental design and statistics}

The experimental design was completely randomized in a factorial $2 \times 4$ (two water conditions: control and water deficiency, and four time-point evaluations) with 5 repetitions, totaling 40 experimental units. Each experimental unit was composed of a plant/vase.

The ANOVA was applied when there was a significant difference. The means were compared by Tukey's test at 5\% significance level. Moreover, the standard deviations were calculated for each treatment and statistical analyzes performed by ASSISTAT program version 7.7 beta recommended by Silva (2013).

\section{Conclusion}

The suspension of irrigation for 10 days was sufficient to alter the metabolism of young acapú plants. Thus, these results showed that young Acapu plants tolerate a potential water deficit of up to $-2.86 \mathrm{MPa}$, indicating that this species is not susceptible to water suspension. This condition may favor the development and expansion of Voucapoua americana for the recovery of degraded areas in regions with water deficiency.

\section{Acknowledgements}

The Institute of Agrarian Sciences, Laboratory of Biodiversity Studies of Upper Plants in Federal Rural University of Amazonia,, Pará, Brazil and the funding institution: the National Council for Scientific and Technological Development $(\mathrm{CNPq})$ and Coordination for the Improvement of Higher Education Personnel (CAPES).

\section{References}

Albuquerque MPF, Moraes FKC, Santos RIN, Castro GLS, Ramos EMLS, Pinheiro HA (2013) Ecofisiologia de plantas jovens de mogno-africano submetidas à deficiência hídrica e reidratação. Pesq Agropec Bras. 48: 9-16.

Alves GAR (2010) Aspectos ecofisiológicos, bioquímicos e crescimento de plantas jovens de ipê-amarelo (Tabebuia serratifolia (Vahl) Nicholson) em condições de déficit hídrico e alagamento. Thesis (Agrarian Sciences) - Universidade Federal Rural da Amazônia, Belém, Pará.

Centritto M, Loreto F, Chartzoulakis K (2003) The use of low [CO2] to estimate diffusional and non-diffusional limitations of photosynthetic capacity of salt-stressed olive saplings. Plant Cell Environ. 26: 585-594.

Ferreira RG, Cruz AA, Brocki E, Melo MGG (2006) Palmeiras como espécies potenciais para recuperação de áreas degradadas na base de operações Geólogo Pedro de Moura, Coari. In: $1^{\circ}$ Workshop Técnico-Científico da Rede CTPETRO Amazônia, Manaus.

Flexas, J, Medrano H (2002) Drought-inhibition of photosynthesis in $\mathrm{C} 3$ plants: stomatal and non-stomatal limitations revisited. Ann Bot. 89: 183-189.

Gonçalves JFC, Silva CEM, Guimarães DG (2009) Fotossíntese e potencial hídrico foliar de plantas jovens de andiroba submetidas à deficiência hídrica e à reidratação. Pesq Agropec Bras. 44: 8-14.

Gonzáles A, Tezara W, Rengifo E, Herrera A (2012) Ecophysiological responses to drought and salinity in the cosmopolitan invader Nicotiana glauca. Braz J Plant Physiol. 24: 213-222.

Grisi FA, Alves JD, Castro EM, Oliveira C, Biagiotti G, Melo LA (2008) Avaliações anatômicas foliares em mudas de café 'catuaí' e 'siriema' submetidas ao estresse hídrico. Ciênc Agrotec. 32: 1730-1736.

Hong-Bo S, Li-Ye C, Ming-An S (2008) Calcium as a versatile plant signal transducer under soil water stress. Bioessays. 30: 634-641.

Jones HG (2007) Monitoring plant and soil water status: established and novel methods revisited and their relevance to studies of drought tolerance. J Exp Bot. 58: 119-130.

Junior GB, Guerra HOC, Cavalcanti MLF, Lacerda RDL (2008) Consumo de água e eficiência do uso para duas cultivares de mamona submetidas a estresse hídrico. Rev Bras Eng Agríc Ambient. 12: 350-355.

Kozlowski TT (1984) Responses of woody plants to flooding. In: Kozlowski TT (Ed.). Flooding and plant growth. San Diego: Academic.

Larcher W (2006) Ecofisiologia Vegetal. São Carlos- SP: Rima. 531p.

Lorenzi H (2009) Árvores brasileiras: manual de identificação e cultivo de plantas arbóreas nativas do Brasil. 3 ed. Nova Odessa, SP. Instituto Plantarum. 384 p.

Nascimento HHC, Nogueira RJMC, Silva EC, Silva MA (2011) Análise do crescimento de mudas de jatobá (Hymenaea courbaril L.) em diferentes níveis de água no solo. Rev Árvore. 35: 617-626.

Neiman Z (2012) Era verde?: ecossistemas ameaçados. São Paulo. $23^{\mathrm{a}}$ edição. 103p.

Nogueira RJMC, Moraes JAPV, Burity HÁ, Bezerra Neto EE (2000) Alterações na resistência à difusão de vapor das folhas e relações hídricas em aceroleiras submetidas a déficit de água. Rev Bras Fisiol Veg.13:75-87.

Oliveira Neto CF (2010) Crescimento, alterações ecofisiológicas e bioquímicas em plantas jovens de jatobá (Hymenaea courbaril L.) submetidas à deficiência hídrica e ao alagamento. Thesis (Agrarian Sciences) - Universidade Federal Rural da Amazônia, Belém, Pará.

Pagter M, Bragato G, Brix H (2005) Tolerance and physiological responses of Phragmites australis to water deficit. Aquat Bot. 81: 285-299.

Ross ARS, Ambrose SJ, Cutler AJ, Feurtado JA, Kermode AR, Nelson K, Zhou R, Abrams SR (2004) Determination of endogenous and supplied deuterated abscisic acid in plant tissues by high-performance liquid chromatography-electrospray ionization tandem mass spectrometry with multiple reaction monitoring. Anal Biochem. 329: 324-333.

Salisbury FB, Ross CW (2012) Fisiologia das plantas. Cengage learning. 4.ed, São Paulo. 792p.

Santana TA (2012) Relações hídricas e assimilação de carbono em plantas jovens de Jatropha curcas L. sob deficiência hídrica. Dissertation (Plant Production) Universidade Estadual de Santa Cruz, Ilhéus, Bahia.

Santiago AMP (2000) Aspectos do crescimento do sabiá (Mimosa caesalpiniifolia Benth.) em função da 
disponibilidade de água. 63 f. Dissertation (Botany) Universidade Federal Rural de Pernambuco, Recife.

Scalon SPQ, Mussury RM, Euzébio VLM, Kodama FM, Kissmann C (2011) Estresse hídrico no metabolismo e crescimento inicial de mudas de mutambo (Guazuma ulmifolia Lam.). Ci Fl. 21: 655-662.

Sharp RE, Poroyko V, Hejlek LG, Spollen WG, Springer GK, Bohnert HJ, Nguyen HT (2004) Root growth maintenance during water deficits: physiology to functional genomics. J Exp Bot. 55: 2343-2351.

Silva FAZ (2013) ASSISTAT Versão 7.7 beta Homepage http://www.assistat.com DEAG-CTRNUFCG.
Silva JRR (2009) Comportamento ecofisiológico de plantas jovens de andiroba (Carapa guianensis aubl.) sob dois regimes hídricos. Dissertation (Agronomy) Universidade Federal Rural da Amazônia, Belém, Pará. Slavick B (1979) Methods of studyning plant water relations. Springer - Verlag, New York.

Taiz L, Zeiger E (2013) Vegetal physiology. 5.ed. Porto Alegre: Artmed, $918 \mathrm{p}$

Zhang SQ, Outlaw YWH (2001) Abscisic acid introduced into the transpiration stream accumulates in the guard cell apoplast and causes stomatal closure. Plant Cell Environ. 24: 1045- 1054. 